\title{
Journal of Melittology
}

Bee Biology, Ecology, Evolution, \& Systematics

The latest buzz in bee biology

No. 12, pp. 1-6

11 June 2013

BRIEF COMMUNICATION

\section{The large carpenter bee Xylocopa augusti (Hymenoptera: Apidae): New record for Chile}

\author{
José Montalva ${ }^{1}$, Juan L. Allendes², \& Mariano Lucia ${ }^{3}$
}

\begin{abstract}
The large carpenter bee Xylocopa (Neoxylocopa) augusti Lepeletier de Saint Fargeau, 1841, is here recorded for the first time in Chile. This new record increases to four the number of carpenter bees known for the country. Host plant associations for X. augusti in Chile are provided. A key to the species of Xylocopa Latreille in Chile as well as comments on the presence of $X .(N$.$) bruesi Cockerell in the country are also presented.$
\end{abstract}

\section{INTRODUCTION}

The genus Xylocopa Latreille (Xylocopinae: Xylocopini) comprises approximately 470 described species worldwide (Michener, 2007). These bees are commonly known as carpenter bees owing to their behavior of building nests in dead wood, hollow stems, and structural timbers of human constructions (Hurd \& Moure, 1963; Gerling et al., 1989). About 110 species in 12 subgenera are known in the Neotropical region (Ospina, 2000; Michener, 2007). The diversity of this group in Chile is relatively low when compared to neighboring countries, with only three species recorded to date: Xylocopa (Neoxylocopa) bruesi Cockerell, 1914; X. (Schonnherria) splendidula Lepeletier de Saint Fargeau, 1841; and X. (S.) viridigastra Lepeletier de Saint Fargeau, 1841 (Montalva et al., 2008; Montalva \& Ruz, 2010).

The record of X. bruesi in Chile requires confirmation. This species was first listed by Ruiz (1940) as X. brasilianorum bruesi and subsequently cited by other authors (Ospina, 2000; Moure, 2007; Montalva et al., 2008; Montalva \& Ruz, 2010). The two specimens, one of each sex, from which Ruiz (1940) recorded this species were collected in Azapa Valley in northern Chile and were deposited in the entomological collection of Museo Nacional de Chile. However, the whereabouts of these specimens are unknown. We were not able to locate them in that collection nor in other collections in

\footnotetext{
17056 Cyrus Canyon Road, Kernville, California 93238, USA (montalva.jose@gmail.com).

${ }^{2}$ Paul Harris 603, Las Condes, Santiago, Chile (jrallend@gmail.com).

${ }^{3}$ División Entomología, Museo de La Plata, Universidad Nacional de La Plata, Paseo del Bosque s/n, 1900FWA, La Plata, Argentina (mlucia@fcnym.unlp.edu.ar).

Copyright $\odot$ J. Montalva, J.L. Allendes, \& M. Lucia.

Creative Commons Attribution-NonCommercial-NoDerivs 3.0 Unported License (CC BY-NC-ND 3.0).

ISSN 2325-4467
} 


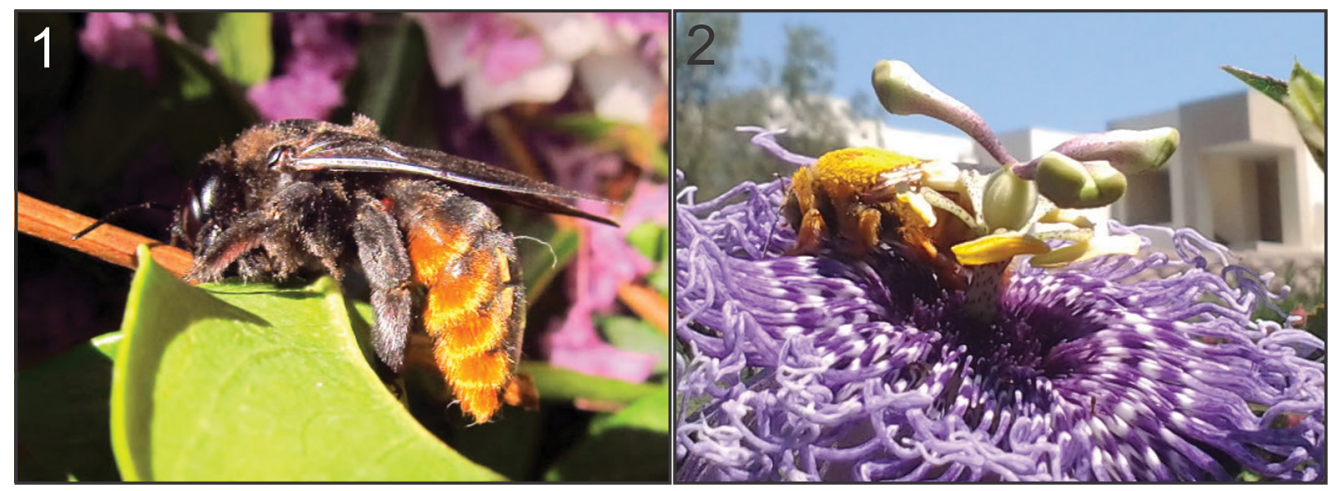

Figures 1-2. Xylocopa (Neoxylocopa) augusti Lepeletier de Saint Fargeau. 1. Female. 2. Male on Passiflora sp. (Passifloraceae).

Chile, namely the Instituto de Entomología of the Universidad Metropolitana de Ciencias de la Educación, Pontificia Universidad Católica de Valparaíso, and the collection Flaminio Ruiz in San Pedro Nolasco.

In the entomological collection of the Museo de La Plata, Argentina, we found a specimen from northern Chile with the following labels: //Pocono-Norte de Chile, 2. 52, R. Cortes col. // [handwritten] and //? Tricuspids (=tricuspidifera)// [handwritten]. Based on photographs of the type of X. brasilianorum bruesi deposited in the American Museum of Natural History, New York (AMNH), this specimen appears not to be conspecific with that species. It differs from the type of $X$. brasilianorum bruesi in the shape and orientation of the lateral tubercles of the labrum, wing coloration, and length of setae on the second to fourth terga. Such differences also were pointed out to us by J.S. Ascher (AMNH), who has examined also specimens from northern Chile and that are identified as X. bruesi at the U.S. National Museum of Natural History, Smithsonian Institution, Washington, D.C.; Laurence Packer collection, York University, Toronto, Canada; and AMNH. Thus, the Xylocopa specimens from northern Chile appear to be a different species of uncertain identity. Further studies are needed to clarify this as well as other taxonomic issues for South American Xylocopa. For example, Hurd (1978: 52) mentioned that X. bruesi, X. (N.) bariwal Maidl, 1912, and X. (N.) lachnea Moure, 1951 seemed to be closely related and may represent a single species.

Herein we record X. (N.) augusti Lepeletier de Saint Fargeau, 1841, for the first time in Chile. Five female specimens of this species were collected (vide infra) and additional specimens were observed in central Chile from December 2012 to March 2013. We also provide host plant associations and a key to the species of Xylocopa of Chile. We hope that this contribution draws the attention of melittologists toward a better understanding of the carpenter bee fauna of the country.

\section{SYSTEMATICS}

Genus Xylocopa Latreille

Subgenus Neoxylocopa Michener

Xylocopa (Neoxylocopa) augusti Lepeletier de Saint Fargeau, 1841

(Figs. 1-4)

Diagnosis: Females of X. augusti are large, robust bees, 23-28 mm long, and can be distinguished easily from all other large carpenter bees in Chile, including X. bruesi, 


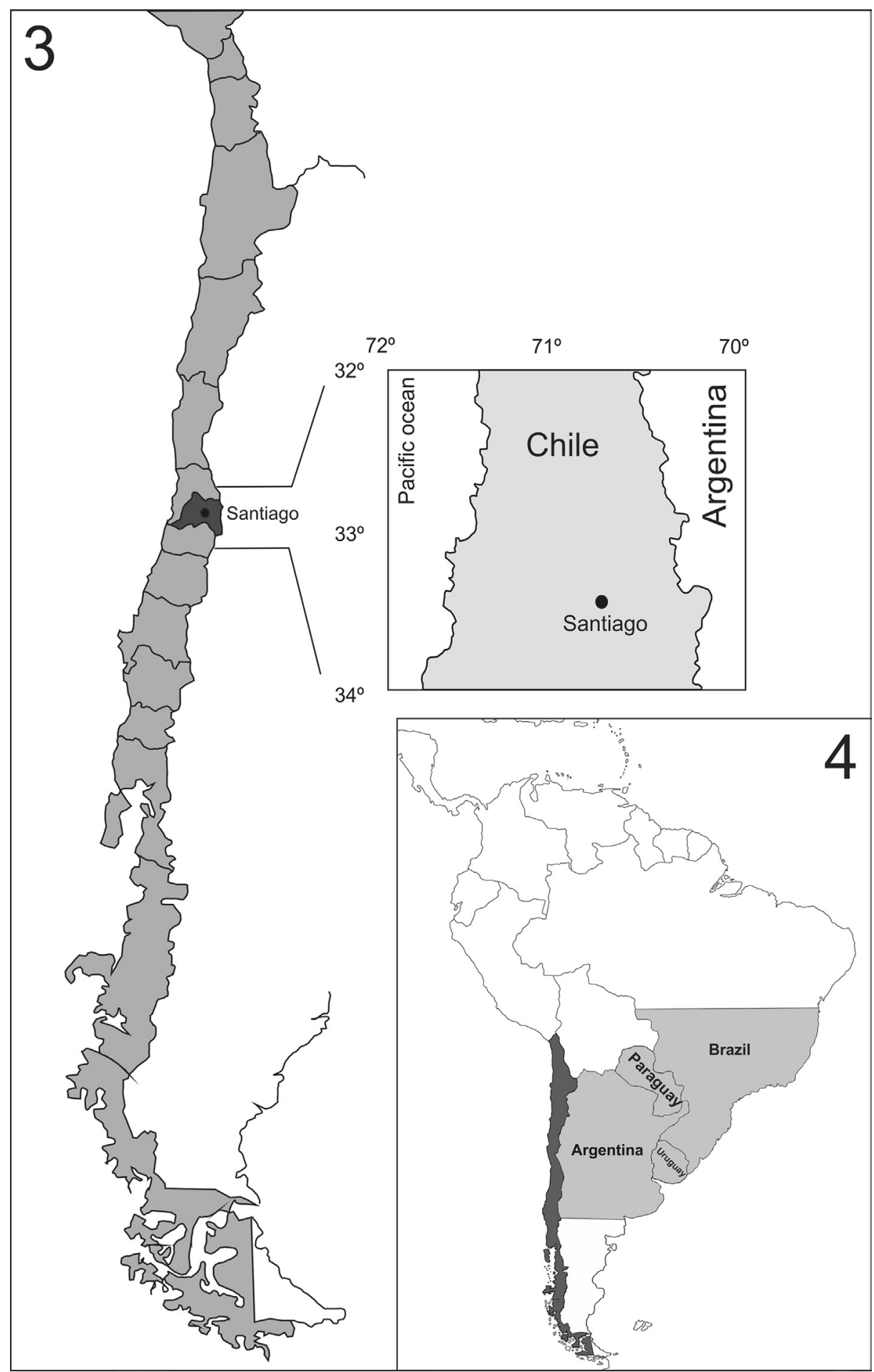

Figures 3-4. Distribution of Xylocopa (Neoxylocopa) augusti Lepeletier de Saint Fargeau. 3. New record in central Chile (Santiago, Metropolitan area). 4. South American countries (in gray) from which this species is currently known (Moure, 2007). 
by the black body integument with conspicuous ferruginous setae along the sides and apex of the metasoma and the wings dark brown with violet iridescence (Fig. 1). As in other species of Neoxylocopa Michener, males (Fig. 2) are tawny and have two well separated tufts of setae on the ventral surface of the metatibia (Brèthes, 1916; Hurd \& Moure, 1961).

New ReCords: Chile: 1, (Metropolitan region), Quinta Normal, Santiago (3326'31.33"S, 7040'54.16"W, 580 m.a.s.l), 24 Jan 2013, J.L Allendes-A. Figueroa (foraging on Passiflora coerulea L.); 1 , , idem, Vitacura ( $33^{\circ} 22^{\prime} 45.05^{\prime \prime} \mathrm{S}, 70^{\circ} 32^{\prime} 27.81^{\prime \prime} \mathrm{W}, 1200$ m.a.s.l), 10 Feb 2013, J.L Allendes (foraging on Passiflora sp. L.); 19, idem, Vitacura, (33'22'45.05"S, 70³2'27.81"W, 1200 m.a.s.l), 20 Feb 2013, J.L Allendes (foraging on

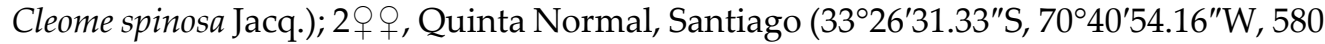
m.a.s.l), 1 March 2013, A. Figueroa (foraging on Passiflora coerulea). Specimens are deposited in the following institutions in Chile: Museo Nacional de Historia Natural, Instituto de Entomología of the Universidad Metropolitana de Ciencias de la Educación, and San Pedro Nolasco, Santiago.

Floral Records in Chile: Specimens were collected foraging on flowers of Cleome spinosa Jacq. (Cleomaceae), Passiflora coerulea L. (Passifloraceae) and Passiflora sp. Several individuals (males and females) were observed at different locations in Santiago, mainly foraging on Alstroemeria pulchra Sims (Alstroemeriaceae), Agapanthus praecox orientalis F.M. Leight (Agapanthaceae), P. tucumanensis Hook. (Passifloraceae), Quillaja saponaria Molina (Quillajaceae), Robinia pseudoacacia L. (Fabaceae), and Solanum crispum L. (Solanaceae).

Geographical distribution: This species was previously known from Argentina, Brazil, Paraguay, and Uruguay (Moure, 2007) (Figs. 3, 4).

Comments: It is well known that many introductions of carpenter bees are accidental, often caused by undetected nests inside of packaging structures in commercial imports (e.g., Hurd, 1978). This is probably the case for X. augusti. This species might have been introduced to Chile from the Atlantic coast facilitated by the high traffic flow between Mendoza (Argentina) and Santiago (Chile), via the trans-Andean passage. Presumably natural movement of bees from Chile to Argentina have also been documented in recent years, such as the cases of the non-native bumble bees Bombus (Megabombus) ruderatus (Fabricius, 1775) and B. (Bombus) terrestris (Linnaeus, 1758) (Roig-Alsina \& Aizen, 1996; Torreta et al., 2006; Morales, 2007), as well as of several Chilean endemic species that have been reported in Argentina (Montalva \& Ruz, 2010). Nevertheless, the possibility that X. augusti has gone undetected until now cannot be ruled out. More systematic surveys of local bee faunas are needed to detect newly adventive species, to monitor the spread of these species, and to assess their impact on the native biota.

\section{Key to Species of Xylocopa in Chile}

Note that $X$. bruesi is not included in the key because its presence in the country needs to be confirmed (refer to text).

1. Integument of metasomal terga with blue or green metallic tints (subgenus Schonnherria Lepeletier de Saint Fargeau) ......................................................... 2

- Integument of metasomal terga without blue-green tints (subgenus Neoxylocopa Michener) 
2(1). Integument of head and mesosomablack with strong blue tints; female wings subhyaline with weak violet iridescent; male apex of seventh tergum without pair of dentiform projections; bees smaller than $19 \mathrm{~mm}$

X. (S.) splendidula Lepeletier de Saint Fargeau

-. Integument of head and mesosoma black without blue tints; female wing dark brown with green-violet iridescent; male apex of seventh tergum with pair of dentiform projections; bees larger than $22 \mathrm{~mm}$.....

$X$. (S.) viridigastra Lepeletier de Saint Fargeau

3(1). Female T2-6 laterally with ferruginous setae, central Chile (Fig. 1)

X. (N.) augusti Lepeletier de Saint Fargeau

-. Female T2-6 laterally without ferruginous setae, northern Chile

X. (Neoxylocopa) spp.

\section{ACKNOWLEDGEMENTS}

We sincerely thank the curators of the collections visited for providing access to the material in their charge. We also thank John S. Ascher and Handel H. Go for providing information and photographs of X. bruesi and Pablo Vial, Adolfo Figueroa, Jana Toscheva, and Pim Campana for their assistance in the field. This manuscript was improved by comments and suggestions from Leah S. Dudley (University of California Santa Barbara, USA), Rainee Kaczorowski (University of Haifa, Israel), Victor H. Gonzalez (Southwestern Oklahoma State University, USA), and two anonymous reviewers. Support to M.L. was provided by the Consejo Nacional de Investigaciones Científicas y Técnicas, Argentina (CONICET).

\section{REFERENCES}

Brèthes, J. 1916. Le genre “Xylocopa" Latreille dans la République Argentine. Physis, Buenos Aires 2: $407-421$.

Cockerell, T.D.A. 1914. Bees from Ecuador and Peru. Journal of the New York Entomological Society 22(4): 306-328.

Fabricius, J.C. 1775. Systema Entomologiae, sistens insectorum classes, ordines, genera, species, adiectis synonymis, locis, descriptionibus, observationibus. Libraria Kortii; Flensburgi et Lipsiae [Flensburg and Leipzig], Germany; xxxii+832 pp.

Gerling, D., H.H.W. Velthuis, \& A. Hefetz. 1989. Bionomics of the large carpenter bees of the genus Xylocopa. Annual Review of Entomology 34: 163-190.

Hurd, P.D. Jr., \& J.S. Moure. 1961. Systematics of the carpenter bee types (genus Xylocopa Latreille) contained in the collections of the Museo Argentino de Ciencias Naturales "Bernardino Rivadavia," Buenos Aires (Hymenoptera: Apoidea). Journal of the Kansas Entomological Society 34(4): 181-195.

Hurd, P.D., Jr., \& J.S. Moure. 1963 A classification on the large carpenter bees (Xylocopini) (Hymenoptera: Apoidea). University of California Publications in Entomology 29: 1-365.

Hurd, P.D., Jr. 1978. An Annotated Catalog of the Carpenter Bees (Genus Xylocopa Latreille) of the Western Hemisphere. Smithsonian Institution Press; Washington, D.C.; [iii]+106 pp.

Lepeletier de Saint Fargeau, A.L.M. 1841. Histoire Naturelle des Insectes - Hyménoptères [Volume 2]. Roret; Paris, France; 680 pp.

Linnaeus, C. 1758. Systema Naturae per regna tria naturae, secundum classes, ordines, genera, species, cum characteribus, differentiis synonymis, locis [10 $10^{\text {th }}$ Edition, revised]. Laurentii Salvii; Holmiae [Stockholm], Sweden; 824 pp.

Maidl, F. 1912. Die Xylocopen (Holzbienen) des Wiener Hofmuseums. Ein Beitrag zu einer Monographie dieser Gattung. Annalen des Kaiserlichen-königlichen Naturhistorischen Hofmuseums, Wien 26(3-4): 249-330.

Michener, C.D. 2007. The Bees of the World [2 ${ }^{\text {nd }}$ Edition]. Johns Hopkins University Press; Baltimore, MD; xvi+[i]+953 pp., +20 pls. 
Montalva, J., \& L. Ruz. 2010. Actualización a la lista sistemática de las abejas chilenas (Hymenoptera: Apoidea). Revista Chilena de Entomología 35: 15-52.

Montalva, J., L.S. Dudley, \& M.T.K. Arroyo. 2008. First record of Xylocopa (Schonnherria) splendidula Lepeletier, 1841 (Hymenoptera: Apidae: Xylocopini) in the mediterranean zone of Chile. Gayana 72(2): 258-260.

Morales, C. 2007. Introducción de abejorros (Bombus) no nativos: Causas, consecuencias ecológicas y perspectivas. Ecología Austral 17(1): 51-65.

Moure, J.S. 1951. Tres espécies novas de Xylocopa Latreille (Hymenopt.-Apoidea). Dusenia 2(5): 317-322.

Moure, J.S. 2007. Xylocopini Latreille, 1802. In: Moure, J.S., D. Urban, \& G.A.R. Melo (Eds.), Catalogue of Bees (Hymenoptera, Apoidea) in the Neotropical Region: 637-673. Sociedade Brasileira de Entomologia; Curitiba, Brazil; xiv+1058 pp. [Available and updated online at http:// www.moure.cria.org.br/catalogue; last accessed 4 March 2013].

Ospina, M. 2000. Abejas carpinteras (Hymenoptera: Apidae: Xylocopinae: Xylocopini) de la Región Neotropical. Biota Colombiana 1(3): 239-252.

Roig-Alsina, A., \& M. Aizen. 1996. Bombus ruderatus Fabricius, un nuevo Bombus para la Argentina (Hymenoptera: Apidae). Physis, Buenos Aires 51(120-121): 49-50.

Ruiz P.F. 1940. El género Xylocopa Latr. en Chile. Revista Universitaria (Santiago) 25(3): 21-27.

Torretta, J.P., D. Medan, \& A.H. Abrahamovich. 2006. First record of the invasive bumblebee Bombus terrestris (L.) (Hymenoptera, Apidae) in Argentina. Transactions of the American Entomological Society 132(3-4): 285-289. 



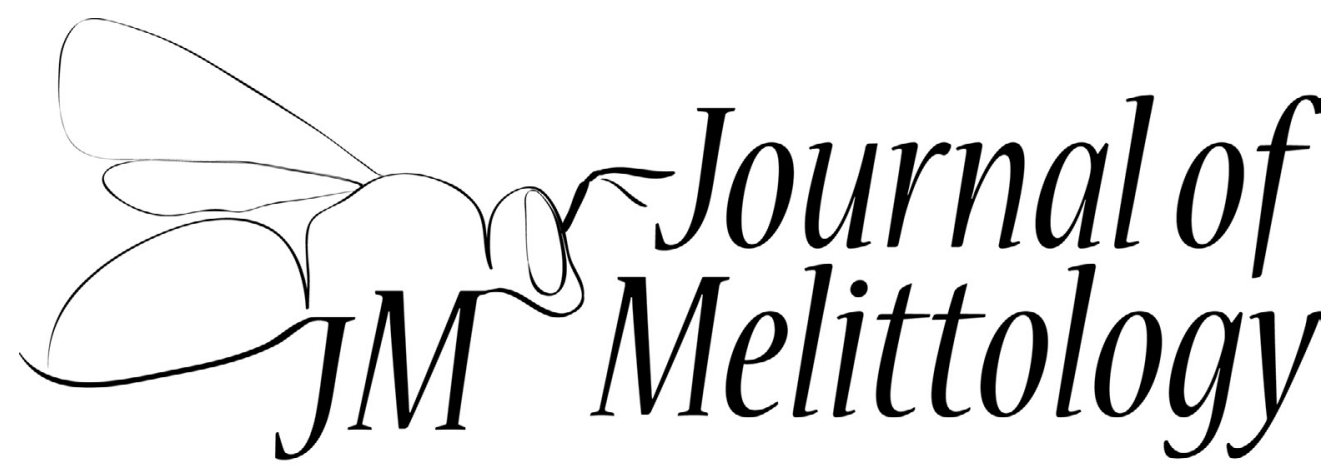

A Journal of Bee Biology, Ecology, Evolution, \& Systematics

The Journal of Melittology is an international, open access journal that seeks to rapidly disseminate the results of research conducted on bees (Apoidea: Anthophila) in their broadest sense. Our mission is to promote the understanding and conservation of wild and managed bees and to facilitate communication and collaboration among researchers and the public worldwide. The Journal covers all aspects of bee research including but not limited to: anatomy, behavioral ecology, biodiversity, biogeography, chemical ecology, comparative morphology, conservation, cultural aspects, cytogenetics, ecology, ethnobiology, history, identification (keys), invasion ecology, management, melittopalynology, molecular ecology, neurobiology, occurrence data, paleontology, parasitism, phenology, phylogeny, physiology, pollination biology, sociobiology, systematics, and taxonomy.

The Journal of Melittology was established at the University of Kansas through the efforts of Michael S. Engel, Victor H. Gonzalez, Ismael A. Hinojosa-Díaz, and Charles D. Michener in 2013 and each article is published as its own number, with issues appearing online as soon as they are ready. Papers are composed using Microsoft Word ${ }^{\circledR}$ and Adobe InDesign ${ }^{\circledR}$ in Lawrence, Kansas, USA.

\section{Editor-in-Chief \\ Michael S. Engel \\ University of Kansas}

\section{Assistant Editors}

Victor H. Gonzalez

Southwestern Oklahoma State University
Charles D. Michener

University of Kansas

Journal of Melittology is registered in ZooBank (www.zoobank.org), archived at the University of Kansas and in Portico (www.portico.org), and printed on demand by Southwestern Oklahoma State University Press. 